\title{
The relationship between urban structure and waterways in Edo, old Tokyo
}

\author{
Kosuke Sakura \\ Chiba University \\ k.sakura0624@gmail.com
}

\begin{abstract}
The purpose of this study is to reveal the relationship between the urban structure and the waterway in Edo, the old Tokyo. The main findings are: 1) The city of Edo was expanded over the river by changing the route of river waters, and limiting the affected area during times of flooding. 2) The canals in the low city were used as water transport between the city and the farmlands. The urban design of the low city was closely related with the canals. 3) According to the drinking water way, there were some hierarchies between the city and the farming villages, warriors and merchants area, etc. 4) The sewerage was not so dirty, because it was consisted of rainwater and gray water. Rather, the sewerage had seemed as a charm against evil. Therefore the drainage channels were used as the boundary between residences, residence and street, towns, and town and farmland. Not only Edo, but also many cities in the world were formed by relating with waterway. In these days, it is important that not only promoting some project of the waterway which is suited as the actual needs like attracting the tourist or creating the beautiful landscape of agriculture, but also rethinking about the waterway which has related with the urban structure or the lifestyle of the citizens in every city.
\end{abstract}

Keywords: urban structure, waterway, Edo

\section{Introduction}

In many regions, waterways were developed as a tool to incorporate river water and spring water into the cities. Cities and canals had a close relationship. It is no exaggeration to say that various cities had been created over the years by incorporating waterway, which was opened suitable for regional climate and geographical feature of the cities.

Nonetheless, as a result of modernization, the cities experienced population boom and urban expansion, and then the waterway hasn't been placed much importance under the situation. This process of disdain for waterway can be seen in a lot of cities of developed countries. In recent years, however, some cities of developed countries began to restore the ancient waterway. The reason of this movement is the growing interest to a switch lifestyle from quantity to quality, a creation of affluent water space, a creation of a recycling-oriented society, etc.

In Japan, there are many cities that have a close relationship with waterways. This relationship is created by the following reason. Japan is a country with large amount of precipitation yearly owing to Asian monsoon. However, in this country, much of the land is steeply inclined. Therefore the rainwater quickly flowed back into the oceans. That is to say, originally, Japan was not a land with abundant water. Nonetheless, Japanese have incorporated the river water in the land by opening many types of waterway in order that the rainwater would takes a long time to reach the oceans. In this way, Japanese have lived an affluent life by incorporating waterway (Satoh \& Takemura, 2014). Especially, Edo -old Tokyo- which is the target city of this study is one of the most famous city to incorporate the river water in the city ably. 
Edo $^{1}$ was one of the major cities in the world during the 17-19th centuries, and the city had an estimated population of more than one million in the early $18^{\text {th }}$ century. Nevertheless, the city had been maintained cleanly until the early $19^{\text {th }}$ century; therefore, the city was highly praised by a lot of visitors from overseas. The important point is that the cleanness city was formed by using the waterway ably. In this study, by focusing attention on the relationship between the urban structure and the waterway of Edo, I bring out how the waterway impact on the urban structure of Edo.

In recent years, many Japanese researchers from diverse fields study about the waterway in Edo. In the case of Architecture, the main purpose has been to create attractive waterfronts by reviving the buried waterway. Then, in the case of environment engineering, the main purpose has been to reconstruct circulating society of water. In the case of urban planning, the main purpose has been to reevaluate the old waterway as region specific asset. In the case of architectural planning, the main purpose has been to figure out the specific structure of farming villages by focusing the waterway, whereas for civil engineering the main purpose has been to maintain the waterway. Despite being found in all fields occasionally, the influence of the waterway to the urban structure of Edo hasn't yet led to well-organized study until now in Japan. However, by analyzing this influence, the relationship among these fields about the waterway is expected to be strong.

\section{The evolution of urban expansion in the Edo city}

According to Ryuko Shimizu (1999), the period of this urban expansion can be divided into three periods (Fig.1). Furthermore, adding the period before the Edo era, I divide it into four periods.

a) The first period: Before the Edo era. In the middle of the $15^{\text {th }}$ century when the Edo castle was constructed by General Dokan Ota, Edo was a small city which was located on naturally undulating terrain. Because the terrain and area for urbanization was limited. It was very important to carry out a lot of civil works in order to be expanded the city of Edo. The first civil work in Edo, changing the route of the Hira River, was carried out during this period. Though this work, the Edo castle and the Edo port where many goods were transported from Kamakura were linked directly. As a result the city of Edo was expanded around the Hira River (Chuo-ku Kyobashi Library, 2007).

b) The second period: the first half of the $17^{\text {th }}$ century / 50 years since the birth of the Edo era. The warriors' residences and some temples were constructed surrounding the Edo castle. Also the land reclamation plan of the Hibiya Bay was carried out by using the soil of the Kanda Mountain. Furthermore, the red of canals was built on the landfill for water transport of all kind of goods. As a result, this landfill was changed to the exiting merchants' town (Koizumi, 1990).

\footnotetext{
${ }^{1}$ Edo is the old Tokyo, and its origin reaches back to the 12th century. However, in this study, focusing attention on the relationship between the change of urban structure and the waterway, I mainly study Edo during the Edo era (1603 - 1868), because the city was rapidly developed in this period. Nevertheless, also the topography and the waterway before the Edo era had a strong effect on the urban structure in Edo. Edo is divided in to areas, the Low and High city. Low city was located along with the Edo Bay in the city of Edo, and the city had a lot of canals. Mainly the merchants and craftsmen lived in this area. High city was located on the Musashino Plateau near the Edo castle. There was a lot of groundwater in this area. Therefore, if someone dug a well, he or she would get the clean groundwater easily. Because of this, mainly the warriors lived in this area.
} 
c) The third period: From the late $17^{\text {th }}$ century to the early $18^{\text {th }}$ century. Great Meireki Fire of 1657, which lasted three days, changed the first situation. Most of the warriors and merchants residences and the temples were burn during three days. However, the government of Edo drew up some new urban expansion plans. According to these plans, a lot of warriors' residences were moved from the surrounding the Edo castle to the nearby farmland, and then merchants also moved to the new lowland area, for example, Asakusa or Yoshiwara area, which was located near the new warriors' residences. The Sumida River played a role as boundary between the city and the farmland in the first and second period (Shimizu, 1999).

d) The fourth period: From the $18^{\text {th }}$ century to the $19^{\text {th }}$ century. The left bank of the Sumida River was developed by moving the warriors and merchants' residences from the city. In this period, the Yokojikken Canal played a role as boundary between the city and the farmland. This evolution of the urban expansion was enabled to carry out a lot of civil works, especially water control of rivers. In the next chapter, I'm going to explain about the water control of rivers (Shimizu, 1999).

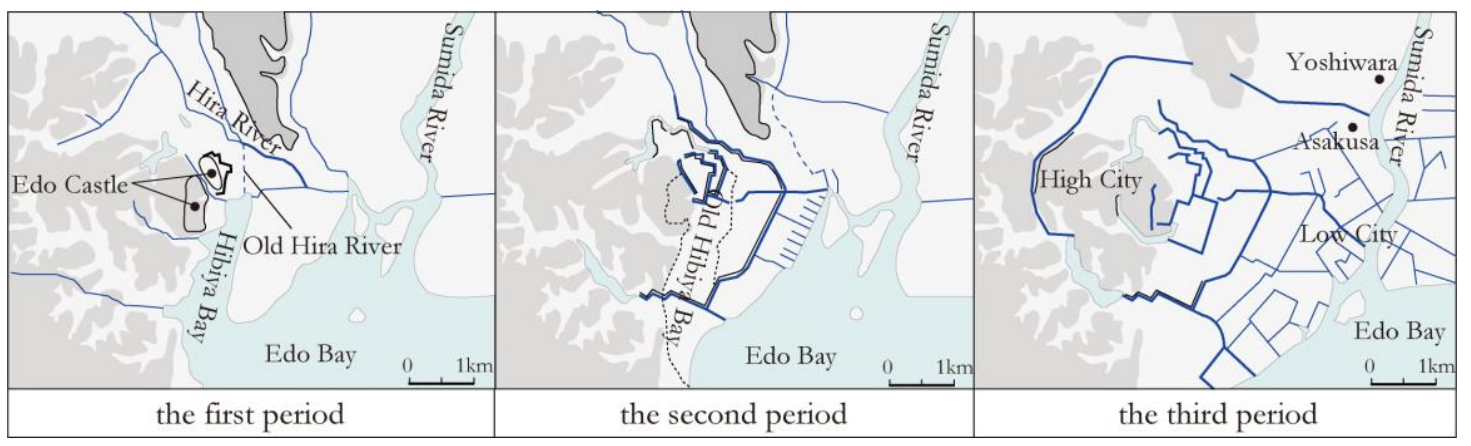

Fig. 1. The evolution of the Edo city

\section{Water control of river and expansion of city and farmland}

\subsection{Changing the route of river and expansion of city and farmland}

Between the Musashino Plateau and the Shimofusa Plateau (toward Chiba), the water system of the Tone Rivers and the Sumida Rivers, which flow into the Edo Bay, formed the floodplain (the Kanto Plain). When Ieyasu Tokugawa (the first Shogun of the Edo period) entered into the Edo castle that was located at the edge of the Musashino Plateau, he overlooked the vast Kanto Plain where people of that time couldn't grow anything. However, he convinced that the Plain could be changed to a vast rice fields as long as the route of the Tone River could be changed the Kanto Plain to the other area (The improvement work on the Tone River). This improvement work is the largest civil work in Japanese history (Suzuki, 1989).

The improvement work was done gradually. At first, the Aino River was cut in 1594. The Shin River and the Akahori River were dug in 1621. Furthermore, several widening work of the rivers were done. As a result, the route of the Tone River was completely changed, and the location of the mouth of the Tone River was changed Tokyo Bay to the Pacific Ocean (Fig. 2) (MLITTTT, 2014). 


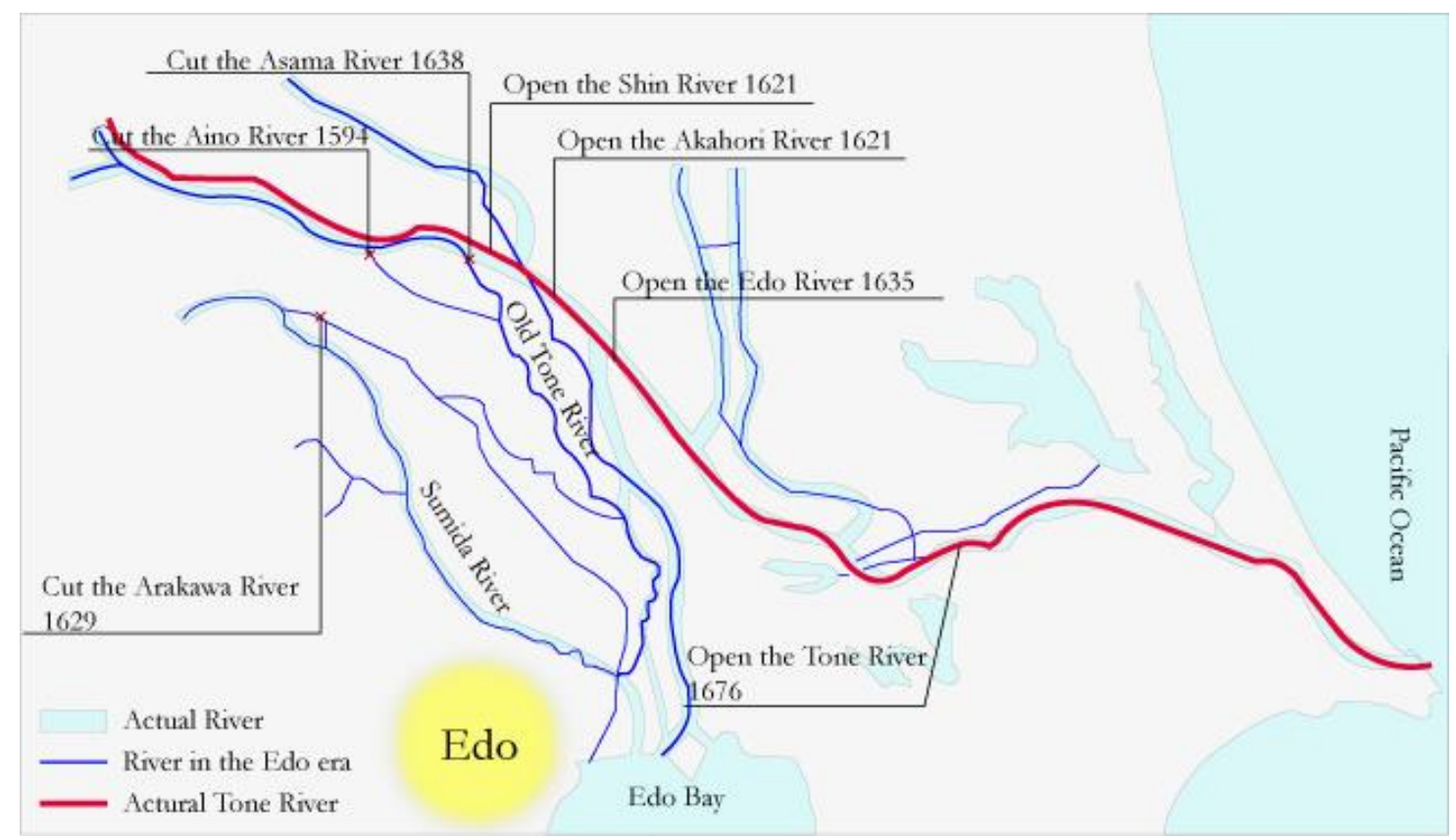

Fig. 2. The improvement work on the Tone River.

Areas of the rice fields in the Kanto Plain were also expanded gradually with progression of the improvement work on the Tone River. According to the book written by Akira Hayami and Matao Miyamoto, a dimension of irrigated farmlands was 2,000,000ha in 1600. However it was rising to 3,000,000 ha in 1700 (Ministry, 2014)). The increasing dimension of farmlands during the 100 years was amazing because the increasing dimension of next 100 years (17001800) was only rising about $200,000 \mathrm{ha}$. The reason of this is that a number of feudal lords throughout Japan developed new rice fields in their own territories in imitation of the improvement work on the Tone River by Ieyasu Tokugawa (Takemura, 2013).

Initially, the Kanto Plain was developed for increasing the dimension of rice fields. However, this Plain was urbanized gradually along with population growth of the city of Edo. For example, the urbanization of Asakusa and Yoshiwara area, in the chapter 2 - the third period, and the urbanization of the left bank of the Sumida River, in the chapter 2 - the fourth period, had close relationship with the process of the improvement work on the Tone River.

\subsection{Floodbanks of the Sumida River and urban expansion}

In parallel with the improvement work on the Tone River, the government of Edo also had to control the Sumida River. The citizens often suffered from floods of the Sumida River. On the other hand, this river was very important to connect between the Edo city and the nearby agricultural villages around the Edo city. Because of this reason, the river couldn't change the route like the Tone River. Since one of the most basic and primitive way of a flood control was to sacrifice a limited area preferentially. In so doing, the other area could be saved.

This way was also used in the city of Edo. In the case of the Edo city, the limited area was selected a left bank of the Sumida River, therefore, this area frequently suffered extensive damage from the floods. Because of this, the area still had been an undeveloped wetland area or rice fields until the middle of the $17^{\text {th }}$ century. After the Great Meireki Fire of 1657, the government of Edo carried out urban expansions in order to reduce the density of the Edo 
city. As a part of these activities, the left bank of the Sumida River was developed, and then lots of merchants' residences, warriors' residences and temples were moved from the Edo city.

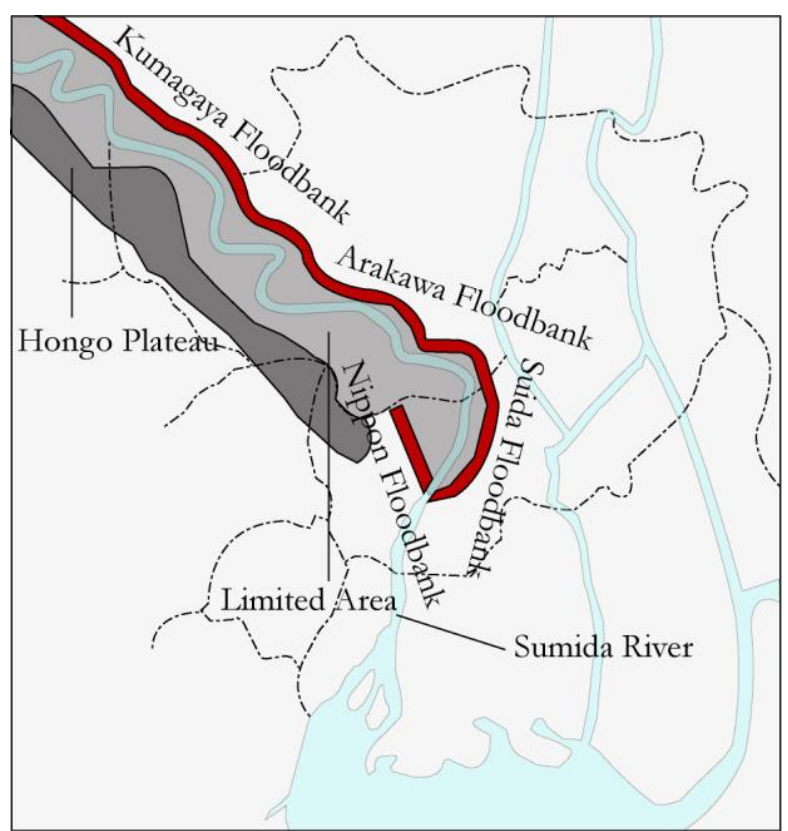

Fig. 3. The improvement work on the Tone River

The government of Edo constructed the Nippon Floodbank, the Sumida Floodbank, the Arakawa Floodbank and the Kumagaya Floodbank to create a new limited area. The dicks and the Hongo Plateau. In order to maintain and manage the dicks, the government carried out unique plans. One of the plans was moving the Yoshiwara red-light district from the city of Edo to the end of the Nippon Floodbank. Another plan is creating an avenue of cherry trees on the Sumida Floodbank, and inviting first-class Japanese restaurants on the floodbank. As a result, the floodbanks were changed to an area, which flourished throughout a year. As a result, the floodbanks were naturally treaded down by traffic of a lot of people. Furthermore, the citizens became the administrator of the dicks without knowing (Fig. 3) (Takemura, 2013).

\section{The canals in the city of Edo}

\subsection{Roles of the canals}

There were a lot of canals in the low city of Edo. If a waterway was opened in the low city, the waterway would contain seawater. Therefore this waterway wasn't able to use as a drinking water way. However, this waterway was suitable to use as a canal because of slow stream. The city was a city similar to Venice in its characteristics (Jinnai, 1995).

Originally, the purpose of building the canals was to transport all kind of goods from the cities throughout Japan to the city of Edo, just like the canals which were built in the early Edo era were built for transporting a lot of salt from Gyotoku to the city. The canals enabled them to transport a lot of goods free of influence from the ocean current. Also, the canals made it possible to transport easily from the port to the inland.

On the other hand, the canals in Edo had another important role. The city of Edo possessed a unique and highly practical night soil disposal system by using the canals. The night soil 
from every household was collected, and transported nearby farming villages through the canals. It was carried in special "night soil barges". On the other hand, rice and vegetables grown in the farmlands were transported back to Edo by the canals. In other words, there was a functioning resource recycling system linking the city of Edo and the farmlands by using the canals (Seki, 2011; Jinnai, 2013).

\subsection{The relationship between the canals and the urban structure of the low city}

Before the Great Meireki Fire of 1657, the canals were built in the right bank of the Sumida River. The low city was composed of a lot of quadrangular islands which were surrounded by the canals. Each kind of craftsmen lived in the own island.

After the Great Meireki Fire of 1657, the main merchants' town (low city) was moved to the left bank of the Sumida River. The canals were built on a grid in the low land of the left bank. Analyzing urban design of the area, we can understand that the Onagi Canal, which was made to bring salt from Gyotoku to the city in the early period of the Edo era, functioned as physical axis in the urban structure of the area. More specifically, the Tate and the Kitajikken Canal were opened to be positioned parallel to the Onagi Canal. Then, the Oyoko and Yokojikken Canal were opened to be positioned perpendicular to the Onagi Canal. Each area, which was surrounded by the canals, was divided into some rectangular strip-shaped lands, and then a lot of merchants' residences, warriors' residences and Japanese traditional warehouses were constructed on it (Fig. 4) (Jinnai, 2013).

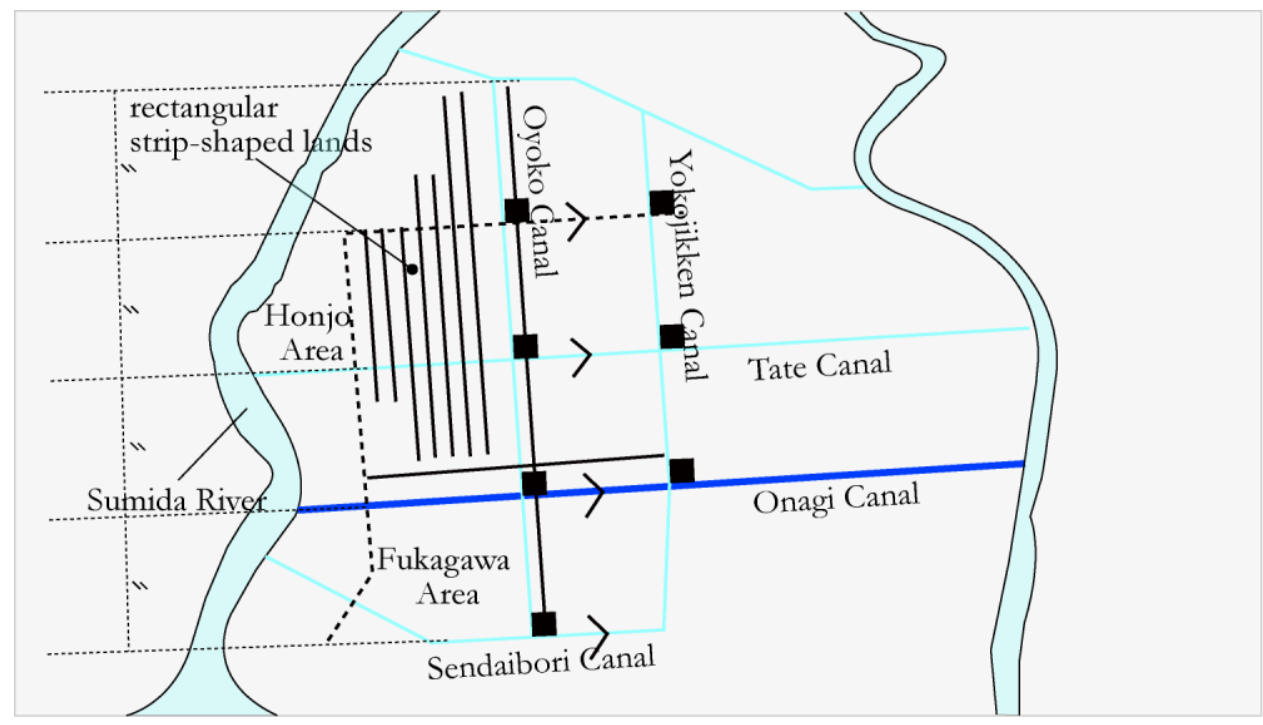

Fig. 4. The Area of Fukagawa and Honjo (the left bank of the Tone River).

\section{Drinking water way and urban structure}

\subsection{Hierarchies in urban structure}

It was one of the most important things to maintain sufficient drinking water for development of the city of Edo. According to the population growth of Edo, the government planned many water supply projects, and carried out them to bring water to the city. For example, the Koishikawa Jo-sui (Jo-sui means drinking water way) was opened in 1590 and the Kanda Jo-sui was opened in 1629. However, after Ieyasu became Shogun, in 1603, Edo 
started to grow even more rapidly, and soon there was not enough drinking water in the city. Therefore new water source was needed for providing drinking water to the citizens.

As a result, the Tamagawa Jo-sui was built in 1653. This Jo-sui flowed from the intake canal of Tone River which was located at the Hamura farming village to the town of Yotsuya. The length of the Jo-sui was about $43 \mathrm{~km}$. After arriving the town of Yotsuya, the Jo-sui was changed from open ditch to close ditch, and branched off a lot of ditches for supplying the drinking water to the large area of the city. Notably, the route of the Jo-sui was selected ridges of the Musasino Plateau, therefore it became possible to bring the water through a wide area by using diversion channels (Oikawa, 2008).

There were a lot of diversion channels on the Musasino Plateau for supplying the fresh water to the farming villages in the middle of the Edo era. However, supplying the water to the city of Edo had priority over to the farming villages. Because of this, supplying water to the diversion channels was limited during times of drought. In short, there was a hierarchy between the Tamagawa Jo-sui for supplying the drinking water to the city of Edo and the diversion channels for supplying the water to the farming villages on the Musasino Plateau (Kosaka, 2006).

Also, there was a hierarchy between the Kanda Jo-sui and the Tamagawa Jo-sui, too. After the completion of the Tamagawa Jo-sui, an area of supplying water by Kanda Jo-sui was mainly the merchants' town which contained the area of Kanda, Nipponbashi, etc. (low city). On the other hand, an area of supplying water by the Tamagawa Jo-sui was mainly the warriors' town which contained the ares of Yotsuya, Kojimati, Akasaka, etc. (high city) (Hatano, 2011).

Furthermore, there was also the other hierarchy in the part of the city which was located in the area of supplying water by Tamagawa Jo-sui. At first the water was supplied to the warriors' residences (high city), and then the residual water was supplied to the merchants' ones (low city) (Fig. 5) (Hatano, 2011).

\subsection{The relationship between structure of farming villages and diversion channels}

The Musasino Plateau is covered with the loamy soil made of volcanic ashes. Therefore it had been difficult to cultivate agricultural produces before the Edo era. However there were farming households and several small farming villages near a few wells, and farmers cultivated very little produces by themselves.

After the Tamagawa Jo-sui was opened, diversion channels were opened near exiting farming households or small villages, and then the periphery of the channels was changed form wild lands to households. As a result some farming villages were formed near the channels gradually, therefore, the villages had closely relationship with the diversion channels.

As a result, the structure of farming villages was able to be classified as tree types. The first was the type of a village where farmhouses were located along the street to the city of Edo, and then a division channel flowed along the street. This channel was mainly used as the drinking waterway and irrigational channel. The second was a village where farmhouses were relatively concentrated in a small area. Several diversion channels flowed along the concentrated farmhouses. Therefore, these channels were mainly used as the drinking waterway. The third was a village where several farmhouses were scattered on a small area. 
Several diversion channels flowed the boundary of each farmland. Because of this, these channels were mainly used as irrigational channels (Hatano, 2011; Kosaka, 1995).

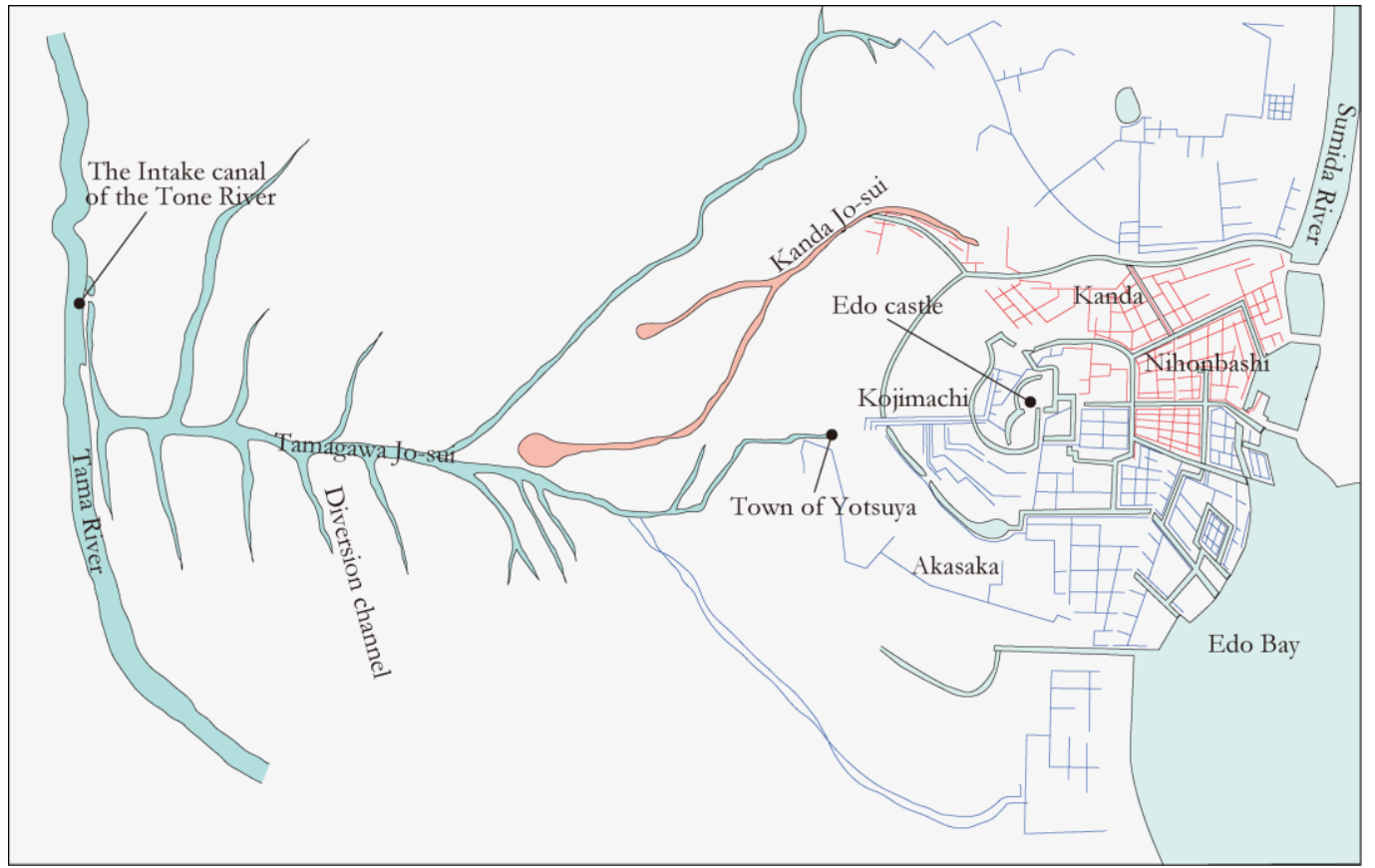

Fig. 5. Tamagawa Jo-sui and Kanda Jo-sui .

In addition, all types of the farming villages had some groves near the farmlands. This reason was following. Normally the farmlands nearby the Edo city used night soil as a fertilizer. The farmers in the Kanto Plain was able to use the night soil of the citizens by water transport. However, the farmers in the Musashino Plateau was able to use little night soil, because this plateau was located higher than the city of Edo, therefore it was difficult to bring the night soil by water transport. For this reason, Mainly, composts were used as a fertilizer in the farmlands of the Musashino Plateau. Making the composts, the farmers had to develop the groves near the farmlands (Fig. 6) (Chida, 1995).

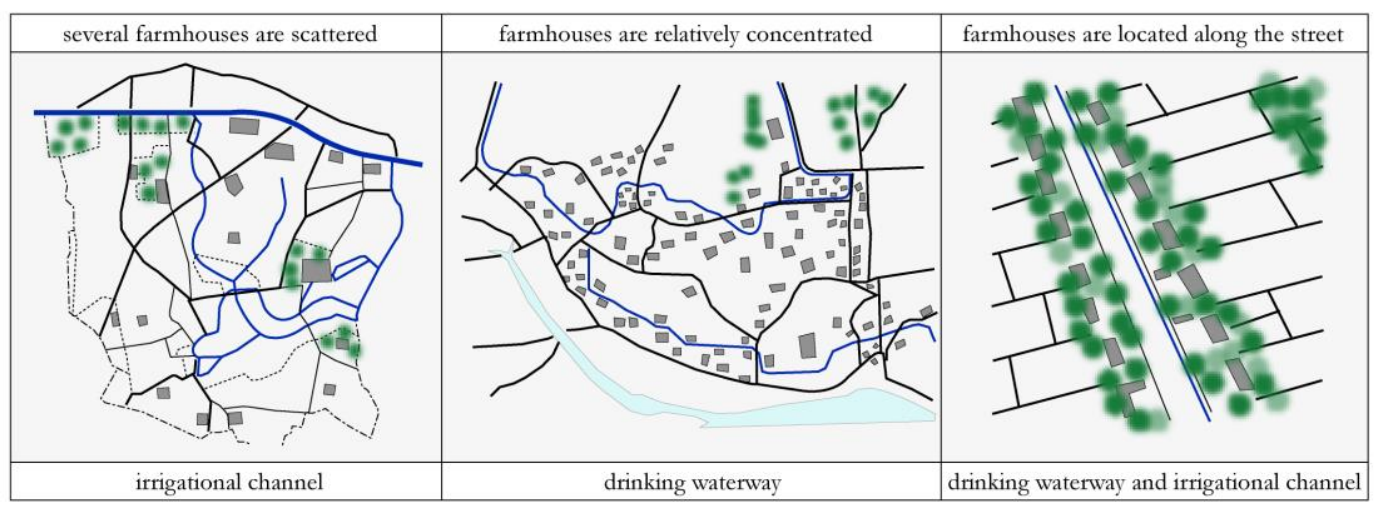

Fig. 6. The type of farming villages and the main role of canal. 


\section{The relationship between urban structure and drainage channels}

According to Syuichi Chida (1995), the sewerage treatment system of households in Japan can be organized by four stages. At first, a toilet is vault toilet type, and rainwater and gray water are flowed to ditches, which is built by citizens easily. The second stage there is a system with toilet and gray water are vault type, and rainwater is flowed to ditch along street in front of the household. The third stage the system is a toilet is vault type, and rainwater and gray water are flowed to a properly-maintained drainage channel. Then the last system is a toilet is flush type, and sewerage (rainwater and gray water) is flowed to a sewage pipe. In generally, the warriors and merchants' residents in the city of Edo was introduced the third system.

In the city of Edo, drainage channels for warriors and merchants' residents were consisted of waterway for rainwater and gray water. Regarding night soil, the soil of every household was collected and transported to nearby farming villages by water transport. In other words, the drainage channels of the city didn't contain the night soil. Therefore, the citizens of Edo didn't think that sewerage was dirty. Rather, the sewerage had seemed as a charm against evil since ancient times (Kurita, 1997). For this reason the drainage channels were built without cover on all kinds of boundary, which are the boundary between residences, a residence and a street, towns, and a town and a farmland.

In the case of merchants' towns in Edo, most streets were lined with houses (machiya) on both sides. Many shops and flourishing businesses also faced the streets. Off the street, in the back, were the row houses (nagaya) in which the citizens made their homes. Wells, garbage dumps, and toilets were communal. Each ward had its drinking water ways and drainage channels (Fig. 7).

The sewerage generated from merchants' residences flowed through the drainage channels surrounding the households, and then the sewerage flowed along the street which was located in front of the household while meeting several channels. Eventually, it was transported through the rivers or the Edo Bay.

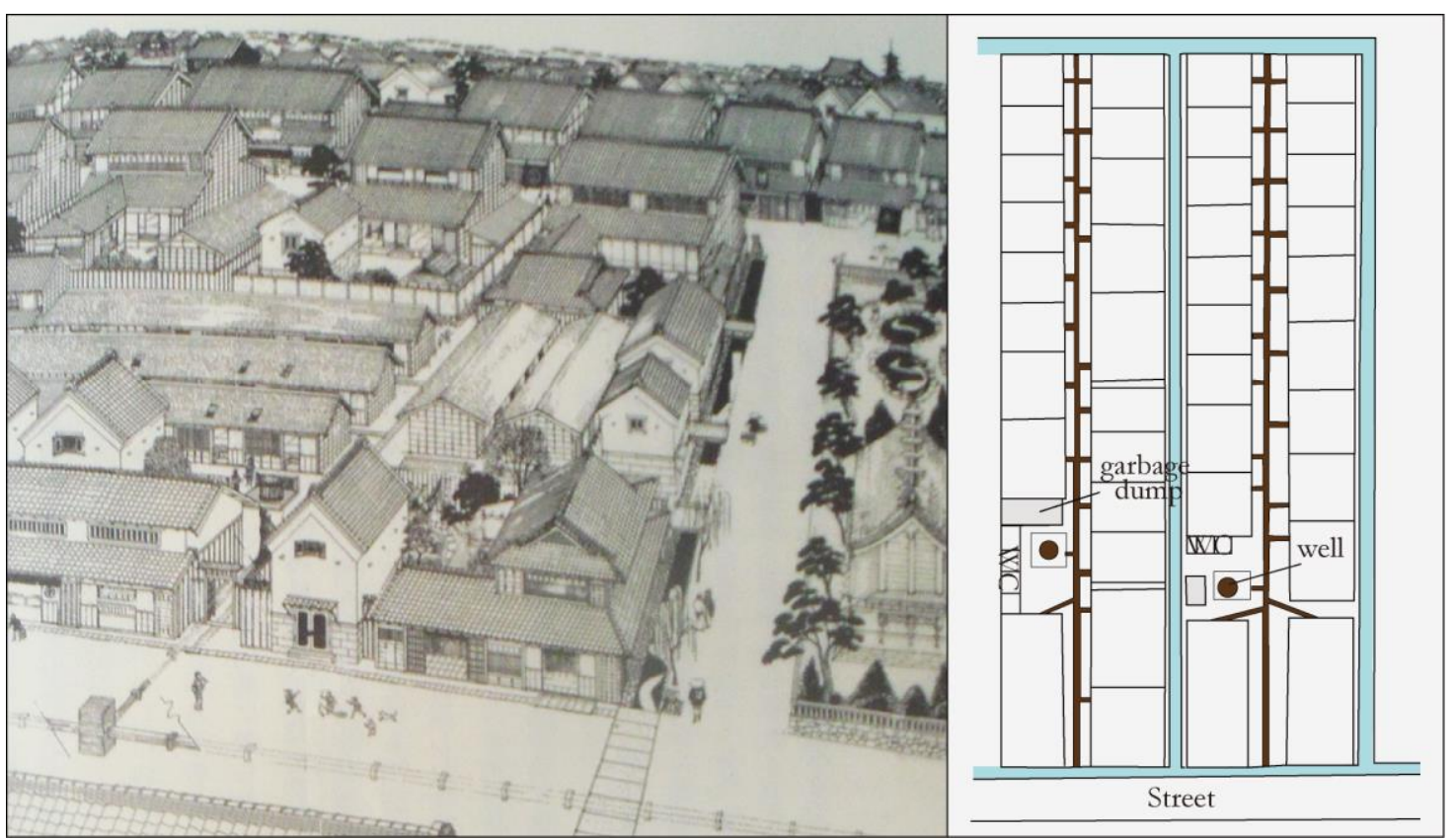

Fig. 7. The drainage channels in the low city. Permanent Exhibition. Edo-Tokyo Museum, Tokyo. 


\section{Conclusion}

In this study, I bought out how the waterway impact on the urban structure of Edo concretely. The summery of each chapter is following.

- The city of Edo was expanded over the river by changing the route of river waters, and limiting the affected area during times of flooding.

- The red of canals was opened on the low land. The canals were used as water transport between the city and the farmlands. The night soils of the city and rice and vegetables of the farmlands were transported by the canals. The urban structure of the low land has closely relationship with the canals, especially, the built canal foremost in the area.

- According to use of the drinking water way, the city of Edo took precedence over the villages. Then, urban structure of the city has closely relationship with hierarchies of the drinking water way. Also, structure of the farming villages has closely relationship with the diversion channels.

- The sewerage was consisted of rainwater and gray water in the city of Edo. Therefore the sewerage was not so dirty. Rather, the sewerage had seemed as a charm against evil. Therefore the drainage channels were used as the boundary between households, household and street, towns, and town and farmland.

As a result, the waterway in Edo closely related with the lifestyle of citizens who lived in varies areas. In these days, it is important that not only promoting some project of the waterway which is suited as the actual needs like attracting the tourist or creating the beautiful landscape of agriculture, but also rethinking about the waterway which has related with the urban structure or the lifestyle of the citizens in every city.

\section{References}

Chida, S. (1995): Edo/Tokyo no Gesuidou no Hanashi (The story of drainage channels in Edo/Tokyo), Gihoudou Press.

Chuo-ku Kyobashi Library (2007): Kyodoshitu Dayori (Letter from the Room of Local History), The Chuo-ku Kyobashi Library.

Hatano, J. (2011): Network toshiteno Edo no Gesui (The sewerage of the Edo City as Network), in a Study Group Working on the Remains of the Edo Era, in Edo no Jo-suidou to Gesuidou (Drinking Water Ways and Drainage Channels in Edo), Yoshikawa Kobunkan, pp.148-171.

Jinnai, H. (1995): Tokyo: A Spatial Anthropology, University of California Press.

Jinnai, H. (2013): Mizu no Toshi Edo/Tokyo (Edo/Tokyo, the Water City), Kodansha Ltd

Koizumi, H. (1990): Edo wo horu (Dig Edo), Kashiwashobou

Kosaka, K. (2006): Musashino Daich no Mizuriyou/Mizuhaibun ni kansuru Kyouzaika no tameno Kisokenkyu (A Basic Study to make Teaching Materials about Use of Water and Distribution of Water in Musashino Plateau), Tokyu Foundation for Better Environment 
Kosaka, K. (1995): Tamagawa Jo-sui to Bunsui (Tamagawa Jo-sui and the Division Channels), Shinjinbutuourai Sya

Kurita, A. (1997): Edo no Gesuidou (The Drainage Channels of Edo), Seiabou Ltd.

Ministry of Agriculture, Forestry and Fisheries: Farmland and Water in Japan (2014):

http://www.maff.go.jp/j/budget/2010_3/pdf/enkatu-haikei1.pdf

MLIT'T'T, (2014): Introduction of the Tone River, Ministry of Land, Infrastructure, Transport and Tourism. Kanto Regional Development Bureau: http://www.ktr.mlit.go.jp/tonejo/ tonejo00185.html

Oikawa, Y. (2008): Edo no Naritachi 3 - Edo no Lifreline (The Scheme of Edo 3 - The Lifeline of Edo), Sinsensha Ltd.

Satoh, T. \& Takemura, S. (2014): KOME - The Art of Rice, 21-21 Design Sight, Tokyo

Seki, H. (2011): Meisaku no Naka no Chikyukankyoshi (The history of global environment), Iwanami publisher.

Shimizu, R. (1999): Mįu Edo/Tokyo Mizu no Kioku (Memory of Water in Edo/Tokyo), Nishida Publisher.

Suzuki, M. (1989): Edo no Kawa, Tokyo no Kawa (River of Edo, River of Tokyo ), Inoue Syoin Ltd.

Takemura, K. (2013): Nihonsi no Nazo ha Chikei de tokeru (Enigmas of the Japanese History can be solved by Topography), PHP Laboratory Ltd. 